\title{
Synthesis, Characterization and Electrochemical Performance of Cobalt Oxides for Supercapacitor
}

\author{
Xiyang Yan, Yansu Wang ${ }^{*}$, Zhiling Ma* \\ College of Chemistry and Environmental Science, Hebei University, National Demonstration Center \\ for Experimental Chemistry Education, Key Laboratory of Analytical Science and Technology of \\ Hebei Province, Baoding 071002, China. \\ *E-mail: 15131200232@163.com, mazhiling838838@163.com
}

doi: $10.20964 / 2018.01 .87$

Received: 28 September 2017 / Accepted: 26 November 2017 / Published: 16 December 2017

\begin{abstract}
Cobalt oxides were prepared by calcinating the precursor which precipitated from $\mathrm{Co}\left(\mathrm{NO}_{3}\right)_{2} \cdot 6 \mathrm{H}_{2} \mathrm{O}$ at $\mathrm{pH}=10.08,9.90,9.75,9.64 \mathrm{NH}_{3}-\mathrm{NH}_{4}{ }^{+}$buffer solution. XRD, XPS and SEM analysis proved that all of the samples were $\mathrm{Co}_{3} \mathrm{O}_{4}$ and $\mathrm{CoO}$ mixing with honeycomb-like morphology. High buffer $\mathrm{pH}$ acted as conducive solution when Co (II) convert to Co (III). Electrochemical performance test indicated that the high Co (III) content is excellent for the electrochemical performance. But when the $\mathrm{pH}$ of the buffer is high, it is not conducive to the uniform distribution of sample particles, which can affect its electrochemical performance. So at the buffer $\mathrm{pH}$ 9.90, a higher Co (III) with excellent uniform degree cobalt oxides was obtained and exhibited best electrochemical performance. And when the current density of $1 \mathrm{~A} \cdot \mathrm{g}^{-1}$, the specific capacitance up to $726 \mathrm{~F} \cdot \mathrm{g}^{-1}$.
\end{abstract}

Keywords: Cobalt oxides; Preparation pH; Supercapacitor; Electrochemical properties

\section{FULL TEXT}

(C) 2018 The Authors. Published by ESG (www.electrochemsci.org). This article is an open access article distributed under the terms and conditions of the Creative Commons Attribution license (http://creativecommons.org/licenses/by/4.0/). 